УДК 347.97/.99

DOI https://doi.org/10.32849/2663-5313/2021.3.50

\title{
Ольга Демидюк,
}

аспірантка кафедри адвокатської майстерності

та міжнародної юридичної практики

Академї адвокатури України

\section{ТЕОРЕТИЧНІ ЗАСАДИ ФОРМУВАННЯ ВИЩОЇ РАДИ ПРАВОСУДДЯ}

У статті здійснено авторський аналіз теоретичних засад формування Вищої ради правосуддя. Системне дослідження законодавчих положень дало можливість виокремити інституційний та проиедурний компоненти формування ВРП. Інституиійний компонент стосується суб'єктного складу як ВРП, так і ї̈ «генераторів» - з'їзу суддів України, Президента України, Верховної Ради України, з’їзду адвокатів України, всеукраїнської конферениії прокурорів, з'їзду представників юридичних виших навчальних закладів та наукових установ. Процедурний компонент визначає особливості проиесу формування ВРП.

Зауважено, шо наявна в Украйні модель органу, відповідального за забезпечення незалежності судової влади, передбачає змішаний склад, за якого членами ВРП є не лише представники суддівської спільноти, а й представники інших правничих професійних кіл. Зазначена особливість, за якої зӥззд суддів обмежений у своєму праві обирати членів ВРП лише серед представників суддівської професії. Водночас інші суб'єкти формування ВРП вправі обирати як серед суддів, так і серед осіб, які таким статусом не володіють, за умови їх відповідності вимогам, встановленим законом.

Аргументовано необхідність законодавчого визначення поняття «правнича професія» для иілей Закону України «Про Вищу раду правосуддя». Обгрунтовано, що за змішаної моделі доречно зберегти нинішній порядок, коли до складу ВРП, окрім суддів (суддів у відставиі), обираються (призначаються) представники від адвокатури, прокуратури та наукової спільноти.

На підставі правових позииій Свропейського суду з прав людини зроблено висновок про недоиільність підходу, за якого до складу ВРП входить Голова Верховного Суду за посадою. Це, на думку автора, порушує задекларований у законодавстві єдиний статус суддів в Україні.

Констатовано та критично оиінено відсутність єдності у процедурі добору кандидатів на посаду члена ВРП залежно від суб'єкта формування. Підтримано ініціативу, яка передбачає обрання (призначення) членів ВРП за результатами відкритого конкурсного відбору. Це, на думку автора, сприятиме забезпеченню відповідності членів ВРП критерію політичної нейтральності, а отже, незалежності ВРП як державної інституиї у лоні судової влади.

Ключові слова: Вища рада правосуддя, склад Вищої ради правосуддя, органи суддівського врядування, судова рада, формування Вищої ради правосуддя.

Постановка проблеми. Сучасний етап судової реформи загострив увагу на органах, які в інфраструктурі судової влади відіграють важливу роль у забезпеченні діяльності судів, а отже, вони опосередковано впливають на її ефективність. Ключове місце серед них відведено Вищій раді правосуддя (ВРП) як органу $з$ конституційним статусом. Як випливає зі статті 131 Основного Закону держави, ВРП відіграє ключову роль у формуванні та функціонуванні професійного, етичного, авторитетного суддівського корпусу. Тому закономірно, що питання ï формування привернуло увагу реформаторів у контексті забезпечення відповідності членів ВРП зазначеним характеристикам (професійність, етичність, авторитет).

Варто лише згадати законодавчі кроки щодо створення при ВРП Комісії з питань доброчесності та етики, одним із завданням якої мала бути оцінка відповідності члена або кандидата до складу ВРП принципам добросовісності та етичних норм судді [1]. Виходячи з їх системного аналізу, Конституційний Суд України дійшов висновку, що повноваження, якими законодавець наділив згадану Комісію, є повноваженнями щодо контролю за діяльністю членів ВРП, які не мають під собою конституційної основи. Конституційний Суд України також підкреслив, що «орган, установу, утворені при конституційному органі, закон не може наділяти контрольною функцією щодо цього конституційного органу» [2].

Визнання неконституційним законодавчих положень, спрямованих на зміну підходу до формування складу ВРП, жодним чином не стало пересторогою та, навпаки, актуалі- 
зувало ініціативи подальших пошуків оптимального механізму формування складу ВРП у руслі суспільного запиту на «добросовісність» її членів.

Аналіз останніх досліджень. Якщо звернутися до наукової літератури, то стає очевидним, що питання формування складу ВРП не досить досліджене. Як правило, превалюють праці, в яких предметом аналізу була Вища рада юстиція, правонаступником якої є ВРП. Зокрема, їх авторами є Р.О. Куйбіда, О.Л. Марчук, І.В. Назаров, І.Л. Самсін, B.I. Шишкін. На сучасному етапі функціонування ВРП окремі аспекти формування iї складу розглядалися у публікаціях Ю.О. Косткіної, Л.М. Москвич, С.В. Прилуцького, А.В. Сухарко, О.З. Хотинської-Нор та інших.

Мета нашої статті - окреслити та проаналізувати теоретичні засади формування складу ВРП у контексті забезпечення авторитету цього конституційного органу суддівського врядування та ефективності його функціонування.

Виклад основного матеріалу. В українській мові слово «формувати» стосовно якогось органу означає організовувати, створювати що-небудь з певної кількості учасників [3]. Тож наш аналіз варто розпочати з дослідження чинних положень нормативно-правових актів, які стосуються питань складу ВРП в частині іiі утворення, організації та повноцінної роботи.

Так, на конституційному рівні (стаття 131 Основного Закону) врегульовано питання формування ВРП у таких аспектах, як:

1) кількісний склад (21 особа) та вимоги до членів ВРП;

2) суб'єкти формування ВРП (призначення/обрання членів ВРП):

- з'їзд суддів України,

- Президент України,

- Верховна Рада України,

- з’ізд адвокатів України,

- всеукраїнська конференція прокурорів,

- з'їзд представників юридичних вищих навчальних закладів та наукових установ.

Як своєрідну конфігурацію цього аспект слід також розглядати положення про належність до складу ВРП Голови Верховного Суду, про що йтиметься далі.

Наведені конституційні положення 3 необхідною мірою деталізації відтворенні у профільному Законі України «Про Вищу раду правосуддя», який, крім іншого, закріплює порядок обрання (призначення) на посади членів ВРП (глава 3).

Отже, системний аналіз зазначених законодавчих норм дає можливість говорити про диференціацію (I) інституційного та (II) процедурного компонентів формування ВРП.

Інституційний компонент стосується суб’єктного складу як ВРП, так і її «генераторів». Процедурний компонент визначає особливості процесу формування ВРП.

Такий підхід, на нашу думку, дозволяє системно підійти до питання, що нами досліджується, у логічному взаємозв'язку обох компонентів з урахуванням можливих наслідків змін одного з них.

I. Отже, як зазначено вище, інституційний компонент (блок) охоплює питання: складу ВРП, тобто безпосередньо ї членів з урахуванням вимог, які до них висуваються; - складу суб'єктів формування/ обрання ВРП. Обидва вони перебувають у тісному взаємозв'язку.

Стосовно складу ВРП слід насамперед зосередитися на такому.

Як випливає зі статті 131 Конституції України та статті 5 Закону України «Про Вищу раду правосуддя», ВРП складається з 21 одного члена, більшість із яких становлять представники суддівського корпусу, оскільки за квотою з'їзду суддів обирається 10 осіб з числа суддів чи суддів у відставці, а Голова Верховного Суду, який перш за все є суддею, входить до складу ВРП за посадою.

Такий підхід загалом не викликає зауважень, оскільки узгоджується 3 існуючими у цій сфері міжнародними стандартами та рекомендаціями. Зокрема, як зауважується у Висновку № 10 (2007) Консультативної ради європейських суддів до уваги Комітету міністрів Ради Свропи про судову раду на службі суспільству, «судова рада може складатися або повністю із суддів, або мати змішаний склад. <..> У разі змішаного складу (судді і не судді) КРСС вважає, що для запобігання будь-якому маніпулюванню чи неналежному впливу значна більшість членів мають бути суддями, обраними іншими суддями». Водночас КРСС вважає, «що склад судової ради повинен відображати настільки, наскільки це можливо, багатоманітність суспільства». Тому, на їі думку, можливо, щоб члени судової ради, які не є суддями, обиралися зі складу визначних юристів, професорів університетів 3 певним професійним стажем або серед видатних громадян. Також не виключається потреба у ширшому представництві фахівців з неюридичних питань (наприклад, менеджменту, фінансів, інформаційних технологій, соціальних наук), зумовлена сучасним управлінням судовою системою [4, с. 455-466].

Отже, змішаний склад ВРП, як аналогу судової ради в Україні, передбачає наявність у її складі не лише осіб у статусі судді 
чи похідного від нього - статусу судді у відставці [5], а й представників інших професійних груп. I в цьому контексті цікавим $є$ ряд моментів.

По перше, слід зазначити те, що лише ключовий суб'єкт формування ВРП - з'їзд суддів обмежений у своєму праві обирати членів ВРП лише серед представників суддівського корпусу. Інші вправі обирати як серед суддів, так і серед осіб, які таким статусом не володіють за умови їх відповідності вимогам, встановленим законом. Отже, не виключена ситуація, за якої ВРП може бути сформована виключно з представників суддівської спільноти, що нестиме ризики загрози корпоративізму та суперечитиме загалом ідеї змішаної моделі ВРП, яка закладена на рівні Конституції України. Як зазначає КРЄС, змішаний склад має перевагу як з огляду на уникнення корпоративізму, протекціонізму та упередженості, так і щодо відображення різних суспільних поглядів. Це надає судовій владі додаткове джерело легітимності [4, c. 455]. 3 огляду на це, доцільно було би передбачити певні запобіжники. Наприклад, що $з$ двох осіб, обраних суб'єктами формування ВРП, за винятком з'їзду суддів, лише один, але не обов'язково, може бути суддею (суддею у відставці). Проте слід зазначити, що оскільки питання складу ВРП з урахуванням суб'єктів його формування та їх квот регулюється ст. 131 Конституції України, то реалізація нашої пропозиції потребує внесення змін до Основного Закону держави.

По-друге, актуальним залишається питання: представники яких саме професій можуть стати членом НКР за квотами Президента України, Верховної Ради України, з'їзду адвокатів України, всеукраїнської конференції прокурорів, з'їду представників юридичних вищих навчальних закладів та наукових установ. Відповідно до статті 131 Конституції України член ВРП має належати до правничої професії та відповідати критерію політичної нейтральності. Закон України «Про Вищу раду правосуддя» конкретизує це положення, передбачаючи у статті 6, що на посаду члена ВРП може бути обраний (призначений) громадянин України, не молодший тридцяти п'яти років, який володіє державною мовою, має вищу юридичну освіту та стаж професійної діяльності у сфері права не менше п'ятнадцяти років, належить до правничої професії та відповідає критерію політичної нейтральності. Проте досі на рівні законодавства не визначено, що таке «правнича професія» і які саме професії слід вважати «правничими». Наразі іiї дефініцію можна знайти лише в одному з варіантів проекту Концепції реформування юридичної освіти, де передбачено, що «правнича професія - це професія, яка передбачає діяльність із застосування права. Ознаками правничої професії є її самоврядність, професійна незалежність та професійна відповідальність. Окремі види правничої діяльності в силу їх соціальної значущості регулюються державою. Регульованими видами правничої діяльності є діяльність на посадах, доступ до яких безпосередньо передбачений розділом VIII «Правосуддя» Конституції України, зокрема діяльність на посадах судді, прокурора та адвоката» [6]. Проте такі підходи критикуються з позиції монополізації правничої професії та наявності передумов певної дискримінації щодо доступу до професії [7].

Таким чином, поки можна стверджувати, що оцінка відповідності кандидата на посаду члена ВРП за критерієм його приналежності до правничої професії здійснюється відповідно до існуючих у свідомості професійної спільноти стереотипів, що грунтуються на уявленні про правничу професію як таку, доступ до якої потребує наявності в особи вищої юридичної освіти.

3 урахуванням наведеного варто звернути увагу, що чинний Класифікатор професій у розділі 2 «рофесіонали» передбачає таку градацію юридичних професій (професій у сфері правознавства) [8]:

\begin{tabular}{|l|l|}
\hline 242 & $\begin{array}{l}\text { Професіонали в галузі правознавства, } \\
\text { прокурорського нагляду, правосуддя } \\
\text { та правоохоронної діяльності }\end{array}$ \\
\hline 2421 & $\begin{array}{l}\text { Професіонали в галузі правознавства } \\
\text { та прокурорського нагляду }\end{array}$ \\
\hline 2421.1 & $\begin{array}{l}\text { Наукові співробітники (правознав- } \\
\text { ство) }\end{array}$ \\
\hline 2422 & Адвокати та прокурори \\
\hline 2423 & Судді \\
\hline 2424 & $\begin{array}{l}\text { Професіонали в галузі правоохорон- } \\
\text { ної діяльності }\end{array}$ \\
\hline $\begin{array}{l}\text { Професіонали кримінально-виконав- } \\
\text { чої служби }\end{array}$ \\
\hline 2429 & $\begin{array}{l}\text { Інші професіонали в галузі право- } \\
\text { знавства }\end{array}$ \\
\hline
\end{tabular}

Отже, доки питання про правничі професії не набуде законодавчого визначення, існує теоретична можливість призначення/ обрання до складу ВРП, наприклад, нотаріуса чи «професіонала в галузі правоохоронної діяльності». Теоретична тому, що професійні спільноти адвокатів, прокурорів, юридичних навчальних закладів мають свій корпоративний інтерес, щоб у складі ВРП були саме представники їх напряму професійної діяльності. Виняток становить лише Президент України. 


\section{$3 / 2021$ судоустРІй}

Жодним чином не применшуючи значимість усіх різновидів професій правничого фаху, на нашу думку, враховуючи коло повноважень, завдань, які стоять перед ВРП як органом суддівського врядування доречно, щоб склад ВРП, окрім представників суддівського корпусу, був представлений репрезентантами лише таких правничих професій, як адвокат, прокурор і науковопедагогічні працівники юридичних вищих навчальних закладів i наукових установ. Необхідність участі перших двох зумовлена їхньою роллю у функціонуванні механізму реалізації правосуддя в державі. Представники ж наукової спільноти здатні забезпечити науково обгрунтований прогрес у реалізації повноважень, якими наділена ВРП.

Окремо, як ми зазначали вище, варто звернути увагу на положення Конституції України, Закону України «Про судоустрій і статус суддів» і профільного Закону, які передбачають, що Голова Верховного Суду входить до складу ВРП за посадою. Адже вони дають підстави для висновку, що Верховний Суд також, хоча й опосередковано, бере участь у формуванні складу ВРП. Обираючи Голову Верховного Суду відповідно до ст. 40 Закону України «Про судоустрій і статус суду» на засіданні Пленуму Верховного Суду, який є його колегіальним органом, до складу якого входять усі судді Верховного Суду, останні, таким чином, обирають автоматично й члена ВРП. На перший погляд, це виглядає логічно з огляду на конституційний статус Верховного Суду як найвищого суду у системі судоустрою України (ст. $125 \mathrm{KoH}-$ ституції України). Це також не заперечується КРЕС, яка зазначає, що обрання членів-суддів «може здійснюватися за допомогою виборів або для обмеженої кількості членів (таких як голова Верховного чи Апеляційного суду) за посадою» [4, с. 457]. Проте, з іншого боку, на нашу думку, це дискримінує інших суддів, які займають посади в місцевих, апеляційних чи вищих спеціалізованих судах, а отже, порушує законодавчо закріплений постулат про єдиний статус суддів в Україні. Адже, як відомо, «серцевину» правового статусу будь-якого суб'єкта становлять його права та обов'язки. У питанні, яке ми аналізуємо, лише судді Верховного Суду в силу зазначених норм законодавства $є$ причетними до формування складу ВРП поза з'їздом суддів.

Вважаємо, що членство у ВРП Голови Верховного Суду за посадою, а не шляхом обрання, є даниною старим традиціям, атавізмом, від якого час відмовитися на кшталт того, як свого часу відмовилися від включення до складу Генерального прокурора України. У справі «Олександр Волков проти України» Європейський суд з прав людини підкреслив, що «спосіб, в який до дисциплінарного органу обираються судді, $€$ також важливим для забезпечення суддівського самоврядування». Крім того, він зауважив, що членство у Вищій раді юстиції не на постійній основі та, як наслідок, отримання своєї зарплатні поза її межами «неминуче означає їхню матеріальну, ієрархічну та адміністративну залежність від їніх головних роботодавців та ставить під загрозу як їхню незалежність, так і безсторонність» [9]. Втрата посади Голови Верховного Суду означає втрату членства у ВРП, що за певних обставин може бути критичним для повноважності ВРП. Адже цілком можливі ситуації, коли тривалий час не обиратиметься Голова Верховного Суду, а його обов'язки виконуватиме інша особа - заступник або суддя, який має найбільший стаж роботи на посаді у Верховному Суді, відповідно до ст. 39 Закону України «Про судоустрій і статус суддів». Виконання цими особами адміністративних повноважень Голови Верховного Суду не створює для них підстав для членства у ВРП.

Отже, доречно, щоб підходи до суб'єктного складу ВРП в частині представництва суддівської спільноти були змінені. Вбачається цілком можливим, щоб не десять, а одинадцять членів ВРП обиралися з'їздом суддів України з числа суддів чи суддів у відставці. Водночас законодавчі положення, які передбачають, що Голова Верховного Суду входить до складу ВРП за посадою, слід виключити.

II. Процедурний компонент формування ВРП вимагає зосередитися на питанні, яким чином обираються (призначаються) на посаду члени ВРП, адже і тут нема єдиного підходу.

Аналіз законодавчих положень свідчить, що процедура обрання (призначення) на посаду члена ВРП різниться залежно від суб'єкта призначення, що також зауважують окремі науковці [10, с. 207].

Так, члени ВРП за квотою з'їду суддів України, з'їзду адвокатів України, всеукраїнської конференції прокурорів і з’їзду представників юридичних вищих навчальних закладів і наукових установ обираються шляхом таємного голосування. Однією з умов, окрім відповідності загальним вимогам, є те, що кандидати повинні бути обрані делегатами відповідного з'їзду. Обраним вважається кандидат, який за результатами таємного голосування отримав більшість голосів обраних делегатів відповідного з'їзду (ст.ст. 10-13 Закону України «Про Вищу раду правосуддя»). 
Натомість Президент України призначає членів ВРП за результатами проведення відкритого конкурсу. Для цього створюється відповідна Комісія 3 проведення відкритого конкурсу з добору кандидатів для здійснення Президентом України призначення членів Вищої ради правосуддя. Саме вона здійснює відбір кандидатів на основі поданих документів і проведених нею співбесід, які рекомендуються для здійснення Президентом України призначення членів ВРП [11]. Тобто для осіб, які прагнуть бути призначеними членом ВРП указом Президента України, передбачено проведення співбесіди. Надалі Президент України вправі на власний розсуд обирати, кого призначити на посаду члена ВРП із числа рекомендованих Комісією за результатами співбесіди кандидатів.

Зрештою Верховна Рада України обирає членів ВРП у порядку, передбаченому ст. 208-1 Регламенту Верховної Ради України. Відповідно до іiі положень добір на посаду члена ВРП здійснюється відкритим рейтинговим голосуванням по кожному кандидату окремо. Потім Верховна Рада обирає членів Вищої ради правосуддя списком, визначеним за підсумками рейтингового голосування, відповідно до кількості вакантних посад відкритим голосуванням більшістю голосів народних депутатів від конституційного складу Верховної Ради. Специфікою процедури обрання є те, що кандидатури на посаду члена ВРП пропонуються депутатськими фракціями (депутатськими групами). А це несе в собі ризики для незалежності та безсторонності майбутнього члена ВРП, який, нагадаємо, повинен бути політично нейтральним. У цьому контексті КРСС зазначає, що «якщо призначення членів - не суддів - все ж таки здійснюється Парламентом, це не повинні бути члени Парламенту, вони повинні обиратися кваліфікованою більшістю, що вимагає значної підтримки опозиції, і це повинні бути особи, котрі дозволяють урізноманітнити представництво суспільства в загальному складі судової ради» [4, с. 461].

Не вдаючись до деталізації наведених існуючих процедур, вважаємо доцільним запровадити єдині для всіх кандидатів на посаду члена ВРП «правила гри». Тому нам імпонує законодавча ініціатива, яка передбачає обрання членів ВРП за результатами відкритого конкурсу. Організацію та проведення конкурсу має забезпечувати створена для цього комісія, яка розглядатиме подані документи, проводитиме співбесіди з кандидатами та за результатами співбесід шляхом відкритого голосування формуватиме спи- сок кандидатів, серед яких можуть обирати надалі членів ВРП суб'єкти обрання (призначення) [12]. Такий підхід, на нашу думку, сприятиме забезпеченню відповідності членів ВРП критерію політичної нейтральності, а отже, незалежності ВРП як державної інституції у лоні судової влади. Крім того, єдині підходи до процедури сприятимуть єдності статусу члена ВРП.

\section{Висновки}

Підсумовуючи, слід зазначити, що з урахуванням численних законодавчих ініціатив, спрямованих на реформування статусу органів суддівського врядування, зокрема і ВРП, питання зміни ії моделі, повноважень тощо $є$ питанням недалекої перспективи. Залишається сподіватися, що законодавець не лише орієнтуватиметься на кращі міжнародні практики, а й дослухатиметься до вітчизняної наукової спільноти, яка прагне, щоб функціонування вітчизняної судової системи було ефективним.

\section{Список використаних джерел:}

1. Про внесення змін до Закону України «Про судоустрій і статус суддів» та деяких законів України щодо діяльності органів суддівського врядування : Закон України від 16.10.2019 № 193-IX. URL: https://zakon.rada.gov.ua/laws/ show/1798-19\#n1090 (дата звернення: 23.02.2021).

2. Рішення Конституційного Суду України від 11.03.2020 № 4-p/2020 у справі за конституційним поданням Верховного Суду щодо відповідності Конституції України (конституційності) окремих положень законів України «Про судоустрій і статус суддів» від 2 червня 2016 року № 1402-VIII, «Про внесення змін до Закону України «Про судоустрій і статус суддів» та деяких законів України щодо діяльності органів суддівського врядування» від 16 жовтня 2019 року № 193-ІХ, «Про Вищу раду правосуддя» від 21 грудня 2016 року № 1798VIII. URL: https://zakon.rada.gov.ua/laws/show/ v004p710-20\#top (дата звернення: 23.02.2021).

3. Словник української мови : в 11 томах. Том 10. Київ,1979. С. 624.

4. Висновок № 10 (2007) Консультативної ради європейських суддів до уваги Комітету міністрів Ради Європи про судову раду на службі суспільству / Документи Консультативної ради європейських суддів: офіц. вид. / упоряд. А.О. Кавакін. 2-ге вид., допов. Київ: Ін Юре, 2017. 816 с.

5. Хотинська-Нор О.З. Статус судді у відставці: проблеми правового регулювання. Вісник кримінального судочинства. 2019. № 2. С. 107-117.

6. Проект Концепції реформування юридичної освіти. URL: https://minjust.gov.ua/m/ proekt-kontseptsii-reformuvannya-yuridichnoiosviti?fbclid=IwAR3lNyeVK-dOx0Mlg2ErlqhCc ZR8PIGjInjZX2_QJWPwF5Z5ua7PR_-e24 (дата звернення: 23.02.2021) 
7. Аналіз проекту Концепції реформування юридичної освіти в Україні. USAID Україна. URL: https://newjustice.org.ua/wp-content/ uploads/2017/09/NJ_Y. Barabash_Report-on-DraftLER-Concept-Paper-and-Recommendations-forImprovement May-22 2017.pdf (дата звернення: 23.02.2021).

8. Класифікатор професій: затверджений наказом Мінекономрозвитку від 10.08.2016 № 1328. URL: http://www.ukrstat.gov.ua/klasf/nac_kls/ op dk003 2016.htm (дата звернення: 23.02.2021).

9. Рішення Європейського суду з прав людини від 09.01.2013 у справі «Олександр Волков проти України» (заява № 21722/11). URL: https://zakon. rada.gov.ua/laws/show/974_947\#Text (дата звернення: 23.02.2021).
10. Косткіна Ю.О. Правовий статус Вищої ради правосуддя: теорія та практика : монографія. Київ: Алерта, 2019. 268 с.

11. Питання добору кандидатів для здійснення Президентом України призначення членів Вищої ради правосуддя : Указ Президента України від 30.10.2019 № 785/2019. URL: https://zakon.rada. gov.ua/laws/show/785/2019\#n12 (дата звернення: 23.02.2021).

12. Проект Закону про внесення змін до Закону України «Про судоустрій і статус суддів» та деяких законів України щодо діяльності Верховного Суду та органів суддівського врядування від 07.07.2020 № 3711-1. URL: http://w1.c1.rada.gov. ua/pls/zweb2/webproc4_1?pf3511=69397 (дата звернення: 23.02.2021).

Olga Demydiuk. Theoretical bases of formation of the Supreme Council of Justice

The article represents the author's analysis of the theoretical bases of formation of the Supreme Council of Justice (SCJ). A systematic study of the legislative provisions made it possible to single out the institutional and procedural components of formation of the SCJ. The institutional component covers both the composition of the SCJ and its "generators" - the Congress of Judges of Ukraine, the President of Ukraine, the Verkhovna Rada of Ukraine, the Congress of Advocates of Ukraine, the All-Ukrainian Conference of Prosecutors, the Congress of Representatives of Legal Higher Education Establishments and Scientific Institutions. The procedural component determines the features of the process of formation of the SCJ.

It has been noted that the current model of the authority responsible for ensuring the independence of the judiciary in Ukraine provides for a mixed composition, in which the SCJ members are not only representatives of the judiciary but also the representatives of the other legal professional circles. It has been noticed a peculiarity, pursuant to which the Congress of Judges is limited in its right to elect the members for the SCJ only among the representatives of judicial profession. At the same time, the other individuals of composition of the SCJ have the right to elect both among the judges and among the persons who do not have such a status, provided that they meet the requirements established by the law.

The necessity of legislative definition of the concept "judicial profession" for the purposes of the Law of Ukraine "On the Supreme Council of Justice" has been argued. It has been grounded that under the mixed model it is appropriate to maintain the existing order, when except the judges (retiredjudges) the representatives from the bar, the prosecutor's office and the scientific community are elected (appointed) to the SCJ.

On the grounds of the legal positions of the European Court of Human Rights it has been concluded that the approach when the President of the Supreme Court is a member of the SCJ by virtue of his/her position is not expedient. In the author's opinion, this violates the unified status of judges in Ukraine declared in the legislation.

Lack of unity in the procedure of selection of candidates for the position of the SCJ member depending on the individual of formation has been stated and critically evaluated. The initiative, which provides for the election (appointment) of the SCJ members based on the results of open competitive selection, has been supported. In the author's opinion, this will help to ensure the compliance of the SCJ members with the political neutrality criterion and, thus, the independence of the SCJ as a state institution within the judiciary.

Key words: Supreme Council of Justice, composition of the Supreme Council of Justice, judicial authorities, judicial council, formation of the Supreme Council of Justice. 